\title{
Konsep pendidikan Islam KH Abdullah bin Nuh dan Relevansinya Dengan Pendidikan Islam Modern
}

\author{
Rudi Mahfudin \\ Universitas Negeri Jakarta \\ RudiMahfudin_IAI13@mahasiswa.unj.ac.id \\ Firdaus Wajdi \\ Universitas Negeri Jakarta \\ Firdauswajdi@unj.ac.id \\ Yusuf Ismail \\ Universitas Negeri Jakarta \\ Yusuf_Syam34@yahoo.com
}

\begin{abstract}
$\mathrm{KH}$ Abdullah bin Nuh is one of Nusantara's scholar who has a significant role in Islamic education. Beside that, he is also concerned with the improvement of Islamic education in Indonesia and vigorously wrote about education. The objective of this research is to increase insight about Islamic education of KH. Abdullah bin Nuh in order to recommend it as reference and to make it applicable with current Islamic education in Indonesia. This proves that KH. Abdullah bin Nuh's thoughts on Islamic education remain relevant to discuss and probably could become alternative recommandation to the development of Indonesian Islamic education.
\end{abstract}

Keywords: Islamic Education, KH. Abdullah bi Nuh, Islamic Modern Education

\begin{abstract}
Abstrak
KH Abdullah bin Nuh merupakan salah satu ulama Nusantara dan yang sangat berpengaruh di dalam dunia pendidikan Islam. Selain aktif menulis dan berkarya KH Abdullah bin Nuh juga sangat memperhatikan perkembangan pendidikan Islam di Indonesia. Tujuan penulisan skripsi ini adalah untuk menambah wawasan dan khazanah mengenai konsep pendidikan Islam KH Abdullah bin Nuh, agar konsep pendidikan Islam bisa dijadikan acuan dan dapat dikombinasi dengan pendidikan Islam yang sudah ada di Indonesia. Dan membuktikan bahwa konsep pendidikan Islam $\mathrm{KH}$ Abdullah bin Nuh masih relevan untuk dibahas dan mungkin dapat digunakan sebagai pedoman konsep pendidikan Islam Indonesia.
\end{abstract}

Kata Kunci : Konsep Pendidikan Islam, KH Abdullah bin Nuh, Pendidikan Islam Modern

\section{A. Pendahuluan}

Pendidikan merupakan salah satu sarana untuk meningkatkan kualitas suatu bangsa, oleh karena itu tolak ukur untuk melihat kemajuan suatu bangsa dapat dilihat dari seberapa besar kontribusi pendidikan didalam negaranya. Kemudian kita melirik sedikit pada Pendidikan Islam bukan menjadi hal yang baru bagi kalangan pemikir, pendidik, dan dunia pendidikan itu sendiri, bahwa Pendidikan Islam dapat menjadi salah satu jawaban atas ketidakteraturan sistem pendidikan yang ada pada masa dekade yang lalu.. 
Akan tetapi, kenyataan yang ada saat ini menempatkan pendidikan Islam pada posisi yang sangat memprihatinkan layaknya masih mencari identitasnya yang mulai tergerus oleh zaman dengan seiring majunya perkembangan di bidang ilmu pengetahuan dan teknologi serta semakin tinggi arus modern mengakibatkat pendidikan Islam dihadapkan pada kondisi materialistis, skularis, dan lainnya.

Secara kelembagaan, pendidikan Islam telah terwujud sejak masuknya Islam ke Indonesia dan banyak memainkan perannya dalam mencerdaskan kehidupan bangsa Indonesia, Tidak sedikit dari tokoh-tokoh dan pemimpin nasional yang sangat berperan penting dalam memajukan pendidikan Islam di Indonesia dan juga menurut beberapa penelitian banyak tokoh-tokoh pembaharu di dalam dunia pendidikan Islam khususnya di Indonesia yang sangat berpengaruh dan memiliki konsep pendidikan yang sangat mumpuni untuk digunakan dan diterapkan salah satunya yaitu yang memiliki konsep pendidikan Islam KH Abdullah bin Nuh. Dari pembahasan diatas muncul pertanyaan utnuk menjawab permasalahan dan solusi di dalam Pendidikan Islam di Indonesia dengan Konsep Pendidikan Islam KH Abdullah bin Nuh yaitu bagaimana konsep pendidikan Islam menurut KH Abdullah bin Nuh dan apa relevansi konsep pendidikan Islam KH Abdullah bin Nuh dengan pendidikan Islam modern saat ini

\section{B. Metode Kajian}

Kajian ini merupakan penelitian Studi Tokoh yang memanfaatkan materi-materi tertulis seperti buku sebagai sumber data primer, artikel dan jurnal untuk menganalisis konsep pendidikan Islam yang dimiliki KH Abdullah bin Nuh serta mengetahui konsep pendidikan islam yang beliau miliki dan relevansinya terhadap pendidikan islam modern saat ini dan melakukan wawancara untuk memperkuat penelitian serta menjawab pertanyaan di dalam penelitian ini.

\section{Kajian Teori}

\section{Pendidikan Islam}

Pendidikan Islam adalah bimbingan jasmani, rohani berdasarkan hukum-hukum agama Islam menuju kepada terbentuknya kepribadian utama menurut ukuran-ukuran Islam. Dengan pengertian yang lain sering kali beliau mengatakan kepribadian utama dengan istilah kepribadian muslim, yaitu kepribadian yang memiliki nilai-nilai agama Islam. ${ }^{1}$

\footnotetext{
${ }^{1}$ Ahmad Harimba dalam Nur Uhbiyati, Ilmu Pendidikan Islam, (Bandung: Pustaka Setia, 1998), cet. 2, h. 5
} 
Tantangan dan masalah-masalah internal pendidikan Islam pasca globalisasi pada hari ini dan masa depan, secara umum adalah sebagai berikut : Pertama, jenis pendidikan yang dipilih dan dilaksanakan, dengan terjadinya perubahan kebijakan-kebijakan dan politik pendidikan. Kedua, persoalan identitas diri lembaga-lembaga Islam tertentu. Dan Ketiga, penguatan kelembagaan dan manajemen suatu lembaga pendidikan Islam. ${ }^{2}$

Penerapan Pendidikan Islam yang berusaha untuk mengembangkan kepentingan dunia dan akhirat adalan pendidikan yang mementingkan Akidah, Akhlak mulia, Budipekerti luhur serta amal saleh, dengan menguasai ilmu pengetahuan dan keahlian teknologi yang fungsional bagi pembangunan bangsa dan Negara Republik Indonesia berdasarkan Pancasila dan UUD $1945 .^{3}$

\section{Pendidikan Islam Modern}

Dan munculnya lembaga Islam modern, mendapat respon yang berbeda dari setiap kalangan, dari kaum yang fanatik dengan tradisionalisme pesantren menuduh lembaga pendidikan modern ini sebagai lembaga pendidikan umum karena tidak mempelajari kitabkitab kuning sebagai dasar ilmu, dan respon positif dari adanya lembaga Islam modern ini yaitu dapat melihat dari perspektif lowongan kerja, mereka berpendapat pembaruan ini sebagai langkah maju dan relevan dengan tuntutan zaman. ${ }^{4}$

Sekolah-sekolah Islam modern yang disebut "elite","unggulan" atau "plus" ini karena beberapa alasan : pertama, sekolah ini menerima siswanya secara kompetitif dari segi kemampuan akademis ataupun keuangan, kedua, guru-guru yang mengajar disini diterima melalui penyaringan dan seleksi, ketiga, sekolah ini memiliki prasarana yang lengkap dibandingkan sekolah Islam negeri lainnya. Dalam hal ini yang membuat sebagian masyarakat yang menginginkan anaknya untuk sekolah ditempat ini akhirnya mengurungkan niatnya karna ketrbatasan kemampuan anak dan masalah biaya atau persyaratan lainnya

\section{Pendidikan Islam Tradisional}

Pendidikan tradisional adalah lembaga pendidikan Islam yang bersistem asrama dan berbasis masyarakat yang menyelenggarakan satu atau berbagai satuan atau berbagai program pendidikan, pendidikan tradisional sangatlah mementingkan penguasaan bahan

\footnotetext{
${ }^{2}$ Marwan Saridjo, Mereka Bicara Pendidikan Islam: Sebuah Bunga Rampai (Jakarta: PT.RajaGrafindo, 2009) h. 20-21

${ }^{3}$ Marwan Saridjo, Mereka Bicara Pendidikan Islam: Sebuah Bunga Rampai (Jakarta: PT.RajaGrafindo, 2009) h. 171-172

${ }^{4}$ Abuddin Nata, Sejarah pendidikan Islam pada periode klasik dan pertengahan, (Jakarta : PT.RajaGrafindo Persada : 2004) cet 1 h.199-200
} 
pelajaran serta mempelajari ilmu keIslaman dan menanamkan jiwa pendidikan tradisional yaitu keikhlasan,mkekeluargaan, kemandirian, kesederhanaan dan ukhuwah. ${ }^{5}$

Dalam hakikatnya pendidikan tradisional tidak kalah dengan pendidikan Islam modern baik dari materi, kurikulum dan lainnya, akan tetapi kekurangan pendidikan tradisional ini terletak pada prasarana yang kurang memadai, pembiayaan pendidikan, ketenagaan(guru) dan manajemen pendidikan hal ini yang membuat pendidikan tradisional mulai tergerus oleh pendidikan Islam modern. ${ }^{6}$

Karakteristik yang diharapkan untuk lulusan dari pendidikan Islam yaitu : agar mereka memiliki dedikasi dan disiplin yang tinggi terhadap tugas dan tanggung jawabnya, mereka harus jujur terhadap diri sendiri dan orang lain, harus memiliki inovasi yang terus mereka kembangkan, dapat mengendalikan diri dan yang paling terpenting adalah harus memiliki Akhlak yang baik, dalam sebuah kutipan buku ${ }^{7}$, sejak juli 1997 krisis yang menimpa Negara Indonesia disebabkan buruknya akhlak sebagian para pemimpin yang akan rakus dengan kekuasaan.

Dan untuk memajukan pendidikan Islam di Indonesia khusunya suatu lembaga atau sekolah yang berlabel Islam harus memiliki sistem pendidikan agama yang dikombain dengan pendidikan umum yaitu diantaranya, ${ }^{8}$ memiliki Pendidikan Agama, Pendidikan bahasa Inggris aktif, Pendidikan keilmuan dan Pendidikan keterampilan kerja sekurangkurangnya satu macam, agar kedepannya pendidikan Islam tidak meniru sistem pendidikan barat karena pendidikan Islam sudah memiliki sistem tersendiri sehingga dapat menghasilkan lulusan yang mampu bersaing dengan lulusan manapun.

\section{D.Hasil dan Pembahasan}

Konsep pendidikan Islam menurut KH Abdullah bin Nuh yaitu ingin mewujudkan umat manusia yang berakhlak dan dapat mengabdikan dirinya kepada Allah dalam segala aktivitas pendidikan apa saja dan dimana saja yang mereka inginkan dan dituntut dirinya agar bermanfaat untuk umat dimanapun dia berada. Dan konsep pendidikan Islamnya yaitu selalu mengikuti perkembangan teknologi dan zaman, apapun metode, sistem dan fasilitas

\footnotetext{
${ }^{5}$ Marwan Saridjo, Mereka Bicara Pendidikan Islam: Sebuah Bunga Rampai (Jakarta: PT.RajaGrafindo, 2009) h.179

${ }^{6}$ Masthu di dalam Nurhasanah Bakhtiar. 2009. Pola Pendidikan Pesantren: Studi Terhadap Pesantren se-Kota Pekanbaru. Diakses dari alamat http://uinsuska.info/tarbiyah/images/jurnal/2009/nurhasanah_pola.pdf pada tanggal 28 april 2017 pukul 13.06

${ }^{7}$ Marwan Saridjo, Mereka Bicara Pendidikan Islam: Sebuah Bunga Rampai (Jakarta: PT.RajaGrafindo, 2009) h.41

${ }^{8}$ Marwan Saridjo, Mereka Bicara Pendidikan Islam: Sebuah Bunga Rampai (Jakarta: PT.RajaGrafindo, 2009) h.42
} 
yang serba modern akan tetapi ajaran yang digunakan harus menyambung sanadnya kepada Rasulullah SAW.

Dan dapat kita lihat dalam perkembangan pendidikan Islam saat ini mereka lebih mementingkan Nilai, Ijazah dan lulusan terbaik, akan tetapi mereka lupa terhadap satu hal dari lulusan mereka yaitu kurangnya Akhlak yang mereka miliki dan dari Lulusan itu apakah mereka nantinya bermanfaat untuk masyarakat disekitarnya akan tetapi kenyataan yang ada mereka mengabaikan hal ini, sehingga modernisasi dalam pendidikan Islam perlu dilakukan agar pendidikan Islam kedepannya tidak hanya mengahsilkan manusia yang berkualitas dengan pengetahuannya saja akan tetapi juga Manusia yang memiliki kualitas diri baik dari Akhlak dan pengetahuannya, sehingga dalam hal ini pendidikan Islam dapat dikatakan berkembang dan meningkatkan kualitasnya serta mampu bersaing dengan pendidikan lainnya.

Semangat pembaharuan dan modernisasi dalam kehidupan KH Abdullah bin Nuh, terlihat bahwa beliau di samping sebagai pemikir dan sosial kemasyarakatan, juga sebagai pemikir praktisi pendidikan sebagaimana terlihat dalam sejumlah karya tulis yang disusunnya dan pengalaman beliau semasa hidupnya yang tidak henti-hintinya belajar dari satu tempat pusat pendidikan ke pusat pendidikan lainnya.

Dari sanalah tampak beliau memadukan antara dua kekuatan, di samping sebagai teoritisi juga praktisi pendidikan. Hal yang menarik dari keduanya adalah bahwa teori yang dirumuskannya adalah diangkat dari sebuah pengalaman praktiknya. Karya-karya beliau lebih banyak bertumpu kepada masalah pendidikan, karangan, tulisan atau buku-buku beliau sudah tersebar melalaui berbagai media berupa buku-buku agama Islam.

Berdasarkan dari hasil yang diperoleh dari penulis dari berbagai buku, jurnal, tesis, skripsi dan wawancara ada beberapa point penting mengenai gagasan pendidikan Islam menurut KH Abdullah bin Nuh, berikut ini penulis akan menjabarkan point-point yang menurut peneliti sebagai konsep pendidikan Islam KH Abdullah bin Nuh.

Dari berbagai karya yang beliau tulis, secara keseluruhan tidak ada yang berjudul Pendidikan dalam arti sebagai Ilmu Pendidikan, akan tetapi didalam buku karyanya banyak dijumpai mengenai gagasan dan pemikiran beliau tentang nilai-nilai luhur yang harus ditanamkan kedalam jiwa masyarakat dan konsep pendidikan Islam yang beliau miliki ditulis oleh murid-muridnya berdasarkan pengalaman mereka belajar dengan beliau, sehingga terpikirlah mereka membuat dan menulis konsep pendidikan Islam yang beliau miliki didalam buku karangan mereka. 
Dalam sebuah buku beliau yang berjudul kitab Al Akhlaq disini penliti mendapat nilai-nilai yang berkaitan dengan pendidikan Akhlaq yaitu mengenai Tingkah laku dan akhlak manusia, dalam hal ini peneliti menemukan satu pembahasan mengenai "Kumaha jalanna ngatik budak "9 yaitu bagaimana cara mengasuh anak, dalam bukunya beliau menjelaskan bagaimana cara orang tua mengasuh anak dan hal ini sangatlah umum untuk masyarakat luas yaitu bagaimana cara mendidik anak yang baik dan benar

Peneliti mengambil intisari dari buku beliau yang didalam nya menjelaskan bahwa seorang anak merupakan amanah dari Allah yang dititipkan kepada ibu dan baoaknya seperti permata yang mahal harganya, dan anak itu di ibaratkan kertas putih dimana ibu dan bapaknya lah yang menjadikan kertas putih itu menjadi sebuah catatan apakah anak ini nanti nya akan baik atau sebaliknya, dalam hal ini ibu dan bapak sangat berpengaruh agar si anak dapat menjadi bermanfaat untuk ibu dan bapaknya kelak di dunia dan di akhirat.

Dalam pemberian rizki, beliau mengatakan bahwa ibu dan bapak harus memberikan rizki yang halal kepada anak agar anak terjauh dari hal-hal yang buruk dan kejahatan, rizki yang di berikan juga mempengaruhi kepada pembentukan watak, karakter dan tingkah laku anak apabila anak diberikan rizki yang halal maka hatinya akan bersih dan menjadi sempurna namun sebaliknya apabila rizki yang diberikan itu tidak halal maka watak anak menjadi kotor dan menjadi pribadi yang kurang baik. Sehingga dalam hal ini orang tua wajib mencarikan anak rizki yang baik dengan berbagai pekerjaan yang sesuai dengan syariat Islam agar pembentukan karakter anak menjadi baik dan berkualitas.

Ibu dan bapak di haruskan untuk mengajarkan anak mengaji Al Qur'an dan Assunah agar hati anak menjadi tenang, baik tingkah lakunya dan menjadi anak sholih dan mereka terhindar dari sifat sirik, jahil, hasad, berbohong dan sifat buruk lainnya. Disini lah peran ibu dan bapak dalam menjadikan anak yang mereka bimbing dan pelihara untuk kedepannya.

Dan didalam kutipan akhir anak itu haru nurut atau patuh, hormat kepada ibu dan bapak agar menjadi harapan ibu dan bapak serta nusa dan bangsa, dan sang anak harus di ajarkan untuk menjalankan perintah Allah seperti sholat, di latih untuk berpuasa, selalu bersyukur dan mematuhi hukum syariat, dan jangan jadikan anak untuk berbuat buruk atau jahat didiklah anak sbagaimana seharusnya.

Dengan demikian KH Abdullah bin Nuh dikatakan sebagai praktisi pendidikan, yaitu karena orang yang mengabdikan seluruh jiwa dan raganya untuk mendidik masyarakat,

9 Abdullah bin Nuh, Kitab Al Aklhaq, (Bogor : Markas Al Ghazaly Al Islami- Indonesia, 2015) hlm $43-52$ 
sebagai seseorang yang tidak mengkotomi suatu pendidikan dan juga sebagai orang yang sangat memperdulikan akan akhlak dan tingkah laku manusia sebagai pedoman hidup mereka, karena Akhlak merupakan hal utama yang harus kita junjung tinggi didalam bermasyarakat, dan masyarakat akan menilai seseorang itu terhaap kepada akhlak yang dimiliki nya.

Dan dari kutipan kitab Al Akhlaq diatas kita dapat perjelas pendidikan akhlak beliau di dalam konsep pendidikan Islam bahwa beliau sangat memperhatikan akhlak seseorang dibandingakan ilmu yang dimilikinya, jadi konesp pendidikan yang beliau miliki baik dari visi-misi, tujuan pendidikan, materi pendidikan dan lainnya semua tidak terlepas dari akhlak yang beliau ajarkan kepada mereka dan konsep pendidikan Islam yang beliau miliki perpaduan antara pendidikan Islam tradisional dan pendidikan Islam modern.

Dari berbagai upaya dan kiprahnya dapat diidentifikasikan aspek visi dan misi pendidikan yang di perbaharui oleh KH Abdullah bin Nuh :

Pertama, dari visi pendidikan, apabila visi pendidikan yang dikatakan oleh Prof. Dr. Abduddin Nata, MA. "sebagai sebuah cita-cita, keinginan, angan-angan, khayalan, dan impian ideal yang ingin dicapai yang dirumuskan secara sederhana, singkat, padat dan jelas namun mengandung makna luas, jauh dan penuh makna". ${ }^{10}$

Maka visi dari KH Abdullah bin Nuh adalah “ mewujudkan persatuan ummat (ittihad al-ummah) diseluruh dunia dalam bingkai persaudaraan Islam atas dasar akidah Ahlussunah wal jama'ah". ${ }^{11}$ Dalam visinya KH Abdullah bin Nuh ingin mencerdaskan pikiran dan memperluas pengetahuan ummat dengan mengembalikan ajaran seutuhnya kepada Islam yang mencintai kemajuan, motivasi serta inovasi manusia untuk mengembangkan kreatifitas dan kreasinya dalam kiprahnya di dunia. Rumus dari visi ini dapat di lihat dari kitab Fi Zhilal al-Ka'bah al-Bait al-Haram, yang mengungkapkan harapan dan cita-citanya dengan banyak menyeru dan mengajak umat muslim untuk bersatu. $^{12}$

Dan visi lain dari KH Abdullah bin Nuh yaitu ingin mengajarkan kaum muslim agar tidak phobia terhadap dunia Internasional dan mengambil manfaat dari kemajuan ilmu pengetahuan dan teknologi yang bersifat universal dan juga mendidik umat muslim dewasa dalam menyikapi adanya perbedaan dalam kalangan kaum muslim di dunia Kedua, dari

\footnotetext{
${ }^{10}$ Abuddin Nata, Filsafat Pendidikan Islam, (Jakarta : Griya Media Pratama, 2005) hlm 30

${ }^{11}$ Syafi'I Antonio, KH. Abudllah bin Nuh Ulama Sederhana Kelas Dunia (Jakarta Tazkia Publishing 2015) hlm 84

${ }^{12}$ Tesis Pemikiran pendidikan K.H.R Abdullah bin Nuh oleh Amiruddin Sujadi (UIN Syarif Hidayatullah Jakata, 2008)
} 
misi pendidikan, penyiapan sumber daya manusia yang berilmu amaliah, beramal ilmiyah, berakhlak karimah dan menjunjung tinggi ukhwah Islamiyah ${ }^{13}$.

Selain visi dan misi pendidikan yang dimodernisasi oleh KH Abdullah bin Nuh ada beberapa konsep pendidikan yang beliau perbaharui yaitu Tujuan, Kurikulum, Materi dan Metode, Pendidik, Manajemen Pendidikan dan Bentuk Pendidikan.

\section{Tujuan Pendidikan Islam}

Tujuan Pendidikan Islam yang dahulu dilakukan Nabi bertujuan untuk membina pribadi muslim agar menjadi kader yang berjiwa kuat dan dipersiapkan menjadi masyarakat Islam(mubaligh) dan pendidik yang baik. ${ }^{14}$ Tujuan umum pendidikan Islam adalah membentuk kepribadian seseorang menjadi khalifah atau sekurang-kurangnya mempersiapkan jalan yang menuju pada tujuan akhir manusia, mencapai suatu Akhlak yang senpurna, adalah tujuan akhir dari suatu pendidikan. ${ }^{15}$

Konsepsi tujuan pendidikan Islam KH Abdullah bin Nuh yaitu membentuk kepribadian Islam yang benar-benar menjadi hamba Allah dalam hal ini KH Abdullah bin Nuh menbangkitkan kesadaran setiap manusia berfikir, memahami dan merenungkan dengan akal apa yang sudah digariskan oleh Allah sehingga manusia benar-benar dapat mengenali dan menaati perintah Allah, memiliki Akhlak karimah, mengokohkan akidah, ahlussunah wal-jamaah dan menjunjung tinggi firman-firman Allah. ${ }^{16}$

Dalam modernisasi tujuan pendidikan Islam ini KH Abdullah bin Nuh tidak banyak merubah dari konsep pendidikan Islam sebelumnya dan menepis pendapat bahwa beliau Syiah yaitu dengan membuat karya dan lembaga berorientasi pada Ahlussunah.

Pertama, dari pemikiran dan gagasan beliau merumuskan pemikiran dan gagasan berupa pentingnya nilai luhur yang harus ditanamkan kedalam jiwa setiap masyarakat, dan dalam tujuan ini beliau menegaskan bahwa "Saat ini umat Islam masih kurang memperhatikan dan memperdulikan bagi kemajuan masyarakat" sehingga beliau memperbaharui dari tujuan pendidikan Islam ini dengan Pendidikan Islam bukan hanya untuk diri sendiri saja akan tetapi pendidikan Islam harus digunakan untuk menolong masyarakat agar mereka (masyarakat) dapat menjalankan peran dan tugasnya sebagai warga Negara.

\footnotetext{
${ }^{13}$ Ahmad Zaini Dahlan, muqaddimah Alhijrah minallah-ilallah, (Bogor, 4 Desember 1987) hlm ii

${ }^{14}$ Abuddin Nata, Filsafat Pendidikan Islam, (Jakarta : Griya Media Pratama, 2005) hlm 11

15 Athiyah Al Abrasyi, Dasar-Dasar Penddiikan Islam, (Jakarta : Bulan Bintang :1993) hlm 1

${ }^{16}$ Tesis Pemikiran pendidikan K.H.R Abdullah bin Nuh oleh Amiruddin Sujadi (UIN Syarif Hidayatullah Jakata , 2008) hlm 141
} 
Kedua, terbentuknya kepribadian umat Islam, hal ini menjadi tujuan dalam proses pendidikan dalam versi KH Abdullah bin Nuh. Nilai kepribadian Islam adalah sosok pribadi muslim yang memiliki pola pikir dan sikapnya berdasarkan pada Akidah Islam. Dalam implementasinya seorang muslim wajib terkait dengan segala ketentuan syariat Islam dalam segala aspeknya, baik aspek ibadah, Muamalah dan juga aspek moralitas.

Dari Tujuan pendidikan Islam KH Abdullah bin Nuh diatas, sudah tampak jelas orientasi pendidikan nya bersifat religious-shufistik, hal ini terlihat dari adanya upaya sistematis dan kontinyus dalam meningkatkan level para muridnya. Perjalanan spiritual yang telah digariskan secara sistematis dan kontinyus dilakukan dengan tujuh tahap/pendakian, yaitu: Ilmu dan Ma'rifat, taubat, rintangan, gangguan, pendorong, cacat atau aib, dan syukur ${ }^{17 \& 18}$

Pertama, pendakian Ilmu dan Ma'rifat, KH Abdullah bin Nuh menjelaskan bahwa ketika manusia sadar akan posisinya sebagai hamba Allah, maka kesadaran itu harus dibangun dengan ilmu. Dengan akal pikiran yang dimiliki, manusia harus mencari ilmu yang dapat membimbingnya kepada Ma'rifatnya kepada Allah SWT, sehingga seseorang itu yakin dengan alam gaib dan mengetahui segala perintah dan larangan-Nya. Ma'rifat dan keyakinan inilah yang mendorong seseorang untuk taat beribadah kepada-Nya. ${ }^{19}$

Kedua, Pendakian taubat, selanjutnya, setelah seseorang hamba menjalani pendakian ilmu dan ma'rifat dan kemudian dia sadar bahwa dirinya masih banyak berbuat maksiat dan penuh dosa. Maka dia harus bertaubat kepada Allah agar Allah mengampuni dosanya dan layak menghambakan dirinya kepada-Nya.

Ketiga, Pendakian rintangan, didalam posisi yang sudah mendapat ampunan Allah dari dosa-dosa, akan tetapi dia berfikir bahwa disekitarnya penuh dengan rintangan yaitu kecintaan terhadap dunia, syaitan, hawa nafwa dan lainnya yang akan selalu menghalanginya untuk beribadah, sehingga dia harus berusaha untuk menghadapi fatamorgana dunia ini, memerangi kemuslihatan syaitan, dan menekan hawa nafsu yang akan membuat kita melalaikan ibadah kepada Allah.

Keempat, Pendakian gangguan, setelah melewati rintangan, akan tetapi masih banyak gangguan yang membuat seseorang bimbang, takut akan rizki, musibah, dan ujian lainnya yang Allah berikan, dalam proses ini seseorang hamba harus berpegang teguh pada empat perkara ini yaitu : Tawakal, Tafwidl, Sabar, dan Ridha.

\footnotetext{
${ }^{17}$ Abdullah bin Nuh, Khulashah Minhaj al-Abidin, (Bogor :YIC AlGhazaly) hlm 3

${ }^{18}$ Syafi'I Antonio, KH. Abudllah bin Nuh Ulama Sederhana Kelas Dunia (Jakarta Tazkia Publishing 2015) hlm 71-72

${ }^{19}$ Abdullah bin Nuh, Khulashah Minhaj al-Abidin, (Bogor :YIC AlGhazaly) hlm 4
} 
Kelima, Pendakian pendorong, setelah melewati pendakian gangguan, seseorang masih memiliki sifat malas didalam dirinya yaitu malas dalam beribadah dan berbuat kebaikan. Sehingga seorang memerlukan pendorong atau motivasi untuk dirinya semangat dalam beribadah dan berbuat kebaikan. Sehingga sifat ini disebut sifat raja' dan khauf.

Keenam, Pendakian cacat atau aib, setelah melewati tahap pendakian ini, maka seseorang dapat beribadah tenang dan khusyu', akan tetapi ibadah yang dilakukan dengan susah payah masih terdapat cela atau aib yang hal ini dapat menghancurkan pahala dan membuat amal ibadah seseorang menjadi sia-sia, cela atau aib itu adalah sifat ujub dan ria.

Ketujuh, Pendakian Syukur, pendakian ini merupakan tahapan yang terakhir dilewati seseorang, dari sinilah seseorang harus mendaki lagi untuk mencapai pada level terakirnya, sifat yang harus dimiliki nya yaitu sifat selalu bersyukur, sifat ini yang menunjukan rasa cintanya kita kepada Allah atas segala yang diberikannya kepada kita baik Iman dan Islam, jasmani dan rohani serta masih banyak yang lainnya, sehingga kita dapat melakukan ibadah dan berbuat amal kebaikan serta aktivitas lainnya.

Setelah seseorang melewati tujuh level pendakian, dapat dikatakan seseorang ini berhasil melewati berbagai ujian dalam kehidupannya, Dalam hal ini yang perlu diperhatikan oleh seseorang dalam melakukan suatu tujuan pendidikan dengan melewati berbagai tahapan yaitu seseorang harus memiliki sifat Istiqomah dan ikhlas didalam dirinya agar dirinya selalu melakukan hal ini dengan sepenuh hati karena Allah.

\section{Metode Pendidikan Islam}

Diantara proses belajar mengajar kita tidak luput dalam pembahasan metode pendidikan, Metode adalah suatu cara yang dipergunakan untuk mencapai tujuan yang telah ditetapkan. Dalam kegiatan belajar metode sangat diperlukan oleh guru, dan penggunaanya bervariasi sesuai dengan tujuan yang dicapai, metode pembelajaran bersifat porsedural yang berisi tahapan tertentu. ${ }^{20}$ Dan dalam metode pendidikan Islam ini tidak dapat dibakukan, karena metode yang digunakan harus disesuaikan dengan materi atau bahan ajar yang ada. KH Abdullah bin Nuh neniliki moto dalam metode pendidikan ini yaitu membaca, menulis(muthola'ah) dan Mengarang. ${ }^{21}$ dan terkait dengan metode

\footnotetext{
${ }^{20}$ Eveline Siregar dan Hartini Nara, Teori Belajar dan Pmbelajaran, (Bogor : Ghalia Indonesia 2011, cet 2) hlm 80

${ }^{21}$ Wawancra dengan ust Turmudi Hudri di Ponpes AlGhazaly, Bogor, Jawa Barat pada tanggal 29 Januari 2017
} 
pengajaran pada pendidikan formal terbagi menjadi berbagai metode yaitu: Metode Pengulangan dan Metode Kaderisasi dan Latihan. ${ }^{22}$

a) Metode Pengulangan

Metode ini digunakan KH Abdullah bin Nuh dalam upaya mendapatkan pemahaman dan pendalaman materi yang diberikan, dalam menanamkan pemahaman pelajaran, seseorang murid harus mengulang-ulang pelajaran hingga sepuluh kali setiap membaca. Bahkan beliau mencontohkan upaya mengulang dalam pembacaan kitab "Ihya Ulumuddin" dan "Minhajul Abidin" hingga duapuluh kali membaca hingga menguasainya.

b) Metode Kaderisasi dan Latihan

Dalam metode kaderisasi dan latihan ini murid-murid KH Abdullah bin Nuh dilatih agar dapat menjadi penerus perjuangan beliau selepas mereka belajar di dalam Pesantren AlGhazaly. Mereka dilatih menjadi Imam, mengajar, berceramah, berpidato, membaca kitab dan mengisi pengajian-pengajian yang ada disekitar. Setelah mereka tamat dari AlGhazaly beberapa diantara murid-murid beliau diminta untuk mengajar kembali disana, sebagian ada yang ditugaskan untuk membina majelis ta'lim yang diasuh beliau, dan apabila ada murid yang memiliki kapasitas ilmu yang memadai untuk membina mayarakat. Selain metode pendidikan formal KH Abdullah bin Nuh juga memiliki metode nonformal dalam mengajar di Majelis Ta'lim asuhannya yaitu :Metode Sorogan, Metode Ketauladanan, Metode Nasehat, Metode Kisah-kisah., Metode Halaqah, dan Metode Wirid

\section{Materi Pendidikan Islam}

Materi pendidikan yang dimiliki oleh $\mathrm{KH}$ Abdullah bin Nuh, berdasarkan dari kiprahnya dilembaga pendidikan $\mathrm{KH}$ Abdullah bin Nuh menginginkan materi pendidikan Islam disamping memuat materi pendidikan agama, juga memuat materi umum dan penguasaan pada IPTEK serta keterampilan yang dibutuhkan oleh masyarakat. ${ }^{23}$

Hal ini sejalan dengan tujuan pendidikan, serta adanya kenyataan dimana umat Islam saat itu masih memusuhi ilmu pengetahuan, dan melihat pengetahuan agama dan pengetahuan umum sebagai bidang ilmu yang bersinggungan atau dikotomis. Dan $\mathrm{KH}$ Abdullah bin Nuh ingin mengintegrasikan anatara diantara kedua bidang ilmu ini serta

${ }^{22}$ Syafi'I Antonio, KH. Abudllah bin Nuh Ulama Sederhana Kelas Dunia (Jakarta: Tazkia Publishing 2015) hlm 75-77

${ }^{23}$ Pemikiran pendidikan Kh Abdullah bin Nuh http://pkuulilalbabuika.blogspot.co.id/2013/03/pemikiranpendidikan-kh-abdullah-bin-nuh_521.html diakses pada 5 februari 2017 pukul 12.05 
menghilangkan dikotomi diantara keduanya ${ }^{24}$ dan selama memberikan materi beliau tidak pernah keluar dari pembahasan yang beliau ajarkan, sebelum mengajar beliau selalu muthola'ah terlebih dahulu, dan beliau tidak akan mengajar sebelum hal itu dilakukannya

\section{Guru/Pendidik dalam Pendidikan Islam}

Dalam hal ini $\mathrm{Hj}$. Mursyidah menulis buku yang berjudul "Keutamaan Guru" dan Hj. Mursyidah beliau memiliki cita-cita agar muridnya menjadi guru minimal guru untuk keluarganya. Dan pendidikan Islam sejatinya terletak pada guru atau pendidik, dan guru yang baik untuk mengajar pendidikan Islam yaitu sanad keilmuannya menyambung hingga ke Rasulullah. ${ }^{25}$ Sementara itu, KH Abdullah bin Nuh juga berwasiat dalam upayanya mengingatkan tentang pentingnya posisi sebagai seorang guru. Wasiat nya yaitu :

Pertama, Ikhlas, melanjutkan perjuangan untuk berdakwah dan mendidik masyarakat dalam rangka mencari ridha Allah menuju surga-Nya yang penuh dengan kebahagiaan dan keikmatan yang kekal.

Kedua, Istiqomah, yaitu tidak menyimpang daei Aqidah Ahlussunah wal Jama'ah, setia mengikuti jejak dan mengamalkan teladan Rasulullah SAW, para sahabat, dan para ulama As-salafus shalihin pewaris nabi.

Ketiga, Semangat dalam menuntut dan mengajarkan Ilmu, menjalani pilihan menjadi seorang guru, berarti ia menjadi hamba yang dicintai Allah Swt untuk mendapatkan pahala yang besar dan memperoleh amal seorang guru layaknya Rasulullah.

\section{Manajemen Pendidikan Islam}

Dalam hal manajemen pendidikan, KH Abdullah bin Nuh menyadari benar bahwa untuk memajukan pendidikan perlu adanya manajemen pendidikan yang kuat dan professional. Sehingga dalam hal mewujudkan manajemen yang handal beliau mendirikan Yayasan Islamic Center AlGhazaly lengkap dengan organisasinya yang baik yaitu dengan hal yang sudah dijelaskan diatas.

Yayasan ALGhazaly ini didirikan untuk mengemban dakwah didaerah Bogor dan sekitarnya, dan sangat diupayakan keseluruh belahan dunia, karena itulah, sedapat mungkin gerakan dakwah ini memanfaatkan sarana ilmu pengetahuan dan teknologi, serta membantu program pemerintah Indonesia dalam membina mental bangsa, memajukan

${ }^{24}$ KONSEP PENDIDIKAN: H. ABDULLAH SYAFI'I VS KH. ABDULLAH BIN NUH http://zaijoni2.blogspot.co.id/2012/02/v-behaviorurldefaultvmlo.html diakses pda 5 februari 2017 pukul 12.15

${ }^{25}$ Wawancra dengan ust Turmudi Hudri di Ponpes AlGhazaly, Bogor, Jawa Barat pada tanggal 29 Januari 2017 
pendidikan, menjunjung tinggi syiar Agama Islam, dan menggalang ukhwah Islamiyah, ${ }^{26}$ Yayasan Islamic Center AL-Ghazaly ini membuka sekolah mulai dari TK, SD, SMP, SMA dan SMK Umum akan tetapi memiliki konsep Pesantren ${ }^{27}$

YIC Al-Ghazaly juga memiliki cabang didaerah Bogor yaitu Majelis Al-Ihya dan Majelis Insan Kamil yang membuka sekolah sama seperti YIC Al-Ghazaly dan di YIC AlGhazaly ini KH Musthofa, Ust Turmudi dan lainnya memberdayakan dan mengoptimalisasikan kreatifitas siswa nya salah satunya yaitu membuat kerajinan batik. Sehingga lembaga-lembaga ini telah berkembang menjadi lembaga yang memadukan sistem pesantren(tradisional) dan keungulan dari sistem sekolah yang professional(modern).

\section{Bentuk Pendidikan Islam}

Melihat dari paparan diatas bentuk pendidikan yang dikembangkan $\mathrm{KH}$ Abdullah bin Nuh yaitu meliputi lembaga Formal dan Non-formal, akan tetapi KH Abdullah bin Nuh lebih memfokuskan pada pendidikan nonformal dan mengabdikan dirinya kepada masyarakat untuk mengembangkan potensi yang ada dan untuk pendidikan formal nya lebih banyak diasuh oleh isteri beliau Hj. Mursyidah. ${ }^{28}$ Dan hal ini terbukti juga dari banyaknya majlis ta'lim dan lembaga pendidikan Islam yang beliau asuh dan secara turun temurun di asuh oleh anak dan murid beliau.

\section{Evaluasi Pendidikan Islam}

Evaluasi didalam dunia pendidikan perlu dilakukan oleh pendidik sebagai sebuah penilaian terhadap prestasi atau pencapaian seorang murid, penilaian berawal dari identifikasi dari tujuan pembelajaran dan berakhir dengan evaluasi mengenai seberapa dalam tujuan itu telah dicapai. ${ }^{29}$

Evaluasi pendidikan KH Abdullah bin Nuh lebih menekankan pada proses pelaksanaan dan beliau tidak memerlukan banyak teori akan tetapi lebih focus pada masalah dan substansi, sebagaimana yang telah dijelaskan bahwa KH Abdullah bin Nuh lebih focus pada pendidikan non-formal, maka evaluasi yang dilakukan berbeda dengan pendidikan formal pada umumnya apabila fungsi dan tujuan evaluasi mengukur tingkat keberhasilan dalam proses belajar mengajar.

\footnotetext{
${ }^{26}$ Syafi'I Antonio KH. Abudllah bin Nuh Ulama Sederhana Kelas Dunia (Jakarta Tazkia Publishing 2015) hlm 186-187

${ }^{27}$ Wawancra dengan ust Turmudi Hudri di Ponpes AlGhazaly, Bogor, Jawa Barat pada tanggal 29 Januari 2017

${ }^{28}$ Wawancra dengan ust Turmudi Hudri di Ponpes AlGhazaly, Bogor, Jawa Barat pada tanggal 29 Januari 2017

${ }^{29}$.Eveline Siregar, dan Hartini Nara, Teori Belajar dan Pmbelajaran, (Bogor : Ghalia Indonesia 2011, cet 2) hlm 143
} 
Mengacu pada tujuan evaluasi KH Abdullah bin Nuh, mengukur tingkat keberhasilan muridnya yaitu melihat kemampuan dan keberhasilan para muridnya dalam membina masyarakat dan mendirikan lembaga atau majelis ta'lim, dari sinilah dapat kita lihat evaluasi yang ditawarkannya tidak hanya sebuah item yang instant, akan tetapi bersifat integral sebagai sebuah keseluruhan dari proses kehidupan itu sendiri. ${ }^{30}$

Kalau hal ini dijadikan ukuran keberhasilan, maka pengajaran yang telah dilakukan oleh KH Abdullah bin Nuh sudah cukup berhasil sebab dari 4 majelis ta'lim yang didirikannya sekarang sudah berkembang pesat dan memiliki cabang baik formal maupun non-formal.

\section{Kelebihan dan kekurangan}

Dalam suatu konsep pendidikan seorang tokoh pasti memiliki kelebihan dan kekurangan masing-masing, menurut peneliti kelebihan dari konsep pendidikan $\mathrm{KH}$ Abdullah bin Nuh adalah dari segi metode, cara pemilihan untuk guru, manajemen dan evaluasi.

Dari segi metode KH Abdullah bin Nuh memiliki metode tersendiri dalam mengajar baik formal maupun non formal yang sudah dipaparkan sebelumnya, untuk guru atau pendidik KH Abdullah bin Nuh mempercayakan Alumni atau murid nya untuk mengajar hal ini membuat point plus tersendiri karena tidak banyak dari konsep pendidikan dalam pemilihan guru seperti ini.

Kekurangan dari konsep pendidikan beliau yaitu dalam cara mengajar beliau yang mungkin masih tradisional dan tidak memerlukan banyak teori dalam hal mengajarnya sehingga beliau lebih memfokuskan di dalam pendidikan non-formal dan mengembangkan potensi yang ada di masyarakat. Dan juga kurikulum, YIC Al Ghazali belum memiliki kurikulum tersendiri dalam mengembangkan kinerjanya dalam dunia pendidikan sehingga lembaga ini masih menggunakan kurikulum dari KEMENAG, sehingga hal ini dapat menjadi masukan agar konsep pendidikan Islam beliau menjadi lebih baik dengan memiliki kurikulum tersendiri yang diciptakan dari Anak, Murid dan pengajar YIC Al Ghazali.

\section{E. Penutup}

Konsep pendidikan Islam KH Abdullah bin Nuh merupakan sikap yang baik ditunjukan oleh beliau yang melihat kondisi pendidikan islam di Indonesia saat ini. Konsep pendidikan Islam yang beliau miliki pedoman pada Ajaran Ahlus sunnah terlihat dari

\footnotetext{
${ }^{30}$ Tesis Pemikiran pendidikan K.H.R Abdullah bin Nuh oleh Amiruddin Sujadi (UIN Syarif Hidayatullah Jakata , 2008) hlm 194
} 
berbagai karya dan lembaga pendidikan yang diasuhnya dan beliau juga seorang praktisi pendidikan dimana beliau tidak memandang perbedaan antara pendidikan Umum dan Agama yang sering disebut dengan dikotomi. Dan konsep pendidikan beliau juga tidak lepas dari pendidikan tradisional kemudian beliau mengemas konsep pendidikan tradisional tersebut menjadi modern dan menyesuaikannya dengan pendidikan Islam Modern saat ini.

Dan lembaga pendidikan Islam serta pemerintah dapat mempertimbangkan Konsep Pendidikan Islam KH Abdullah bin Nuh sebagai upaya untuk memajuakan dan menghasilkan kualitas murid yang memiliki Kepribadian Islam, Akhlak yang baik serta mampu bersaing untuk membuktikan bahwa Lembaga pendidikan Islam memiliki kualitas Sumber Daya Manusia yang tidak kalah dengan output dari sekolah Barat ataupun Timur untuk saat ini lebih banyak diminati para orang tua yang ingin mengembangkan potensi yang dimiliki anaknya.

\section{F. Daftar Pustaka}

Al Abrasyi Athiyah , , Dasar-Dasar Penddiikan Islam, Jakarta : Bulan Bintang :1993

Dahlan, Zaini, muqaddimah Alhijrah minallah-ilallah, Bogor, 4 Desember 1987

Masthu di dalam Nurhasanah Bakhtiar. 2009. Pola Pendidikan Pesantren: Studi Terhadap Pesantren se-Kota Pekanbaru. Diakses dari alamat http://uinsuska.info/tarbiyah/images/jurnal/2009/nurhasanah_pola.pdf

Nuh ,Abdullah bin, Khulashah Minhaj al-Abidin, Bogor :YIC AlGhazaly,1987

Nuh, Abdullah bin, Kitab Al Aklhaq, Bogor : Markas Al Ghazaly Al Islami- Indonesia, 2015

Nata , Abuddin, Filsafat Pendidikan Islam, Jakarta : Griya Media Pratama, 2005

Sujadi ,Amiruddin, Pemikiran pendidikan K.H.R Abdullah bin Nuh Tesis UIN Syarif

Hidayatullah Jakata , 2008

Saridjo, Marwan, Mereka Bicara Pendidikan Islam: Sebuah Bunga Rampai Jakarta:

PT.RajaGrafindo, 2009

Syafi'I, Muhammad Antonio, KH. Abudllah bin Nuh Ulama Sederhana Kelas Dunia Jakarta Tazkia Publishing 2015

Uhbiyati Nur, Ilmu Pendidikan Islam, Bandung: Pustaka Setia, 1998), cet. 